\title{
Evaluation of ischemia-modified albumin levels in acne vulgaris patients
}

\section{Akne vulgaris hastalarında iskemi-modifive albümin düzeyinin değerlendirilmesi}

\section{Gülhan Gürel, ๑ Müjgan Karadöl*, ๑ Ceylan Bal**, ๑ Salim Neșelioğlu**, ๑ Emine Çölgeçen}

Yozgat Bozok University Faculty of Medicine, Department of Dermatology; *Department of Biochemistry, Yozgat, Turkey

**Ankara Yıldırım Beyazıt University Faculty of Medicine, Department of Biochemistry, Ankara, Turkey

\begin{abstract}
Background and Design: Acne vulgaris (AV) is one of the most common dermatological diseases seen in late childhood and adolescence. The purpose of this study is to evaluate ischemia-modified albumin (IMA) levels in AV, a cutaneous inflammatory disease.

Materials and Methods: Seventy-four patients between 15 and 30 years of age with clinically diagnosed $A V$, and 60 healthy age and sex matched controls without AV were enrolled in the study. Serum IMA levels were measured using the albumin cobalt binding test. The capacity of cobalt binding to albumin decreases under ischemic conditions. Patient serum is mixed with cobalt chloride and incubated for 5 minutes, during which the cobalt is allowed to bind to the albumin. This is mixed with dithiothreitol (DTT) following incubation, and result in a colored complex with cobalt unbound to albumin for DTT. The resulting colored complex is measured spectrophotometrically at a wavelength of 500 nm.

Results: The mean age of the AV group with AV was $18.54( \pm 3.40)$, and the mean age of the control group was $17.68( \pm 3.37)$. The mean IMA level in the AV patients was $0.82 \pm 0.023$, compared to $0.80 \pm 0.017$ in the control group. The difference between the two groups was statistically significant $(p<0.001)$. No significant difference was determined among the AV subgroups in terms of IMA levels. Conclusion: Our search of the PubMed database revealed no previous studies investigating IMA levels in patients with AV. Keywords: Acne vulgaris, oxidative stress, ischemia-modified albumin

Öz

Amaç: Akne vulgaris (AV), geç çocukluk ve ergenlik çağında sık görülen yaygın dermatolojik hastalıklardan biridir. Bu çalısmada, kutanöz enflamatuvar bir hastalık olan AV'de, iskemi-modifiye albümin (IMA) seviyelerinin değerlendirilmesi amaçlanmışıı.

Gereç ve Yöntem: Çalışmaya klinik olarak AV tanıı konulan 15-30 yaş arasında 74 hasta ile yaş ve cinsiyet açısından eşleştirilmiş AV hastalı̆̆ı olmayan 60 sağlıklı kontrol alındı. Serum iMA düzeyi, albümin kobalt bağlama testi ile ölçüldü. İskemik durumlarda, kobaltın albümine bağlanmasının azaldığı bilinmektedir. Hasta serumu, kobalt klorid ile karıştııııp 5 dakika süreyle inkübe edilir. Bu süreçte kobaltın albümine bağlanması sağlanır. İnkübasyondan sonra ditiyotreitol (DTT) eklenerek karıştırılır ve DTT'nin albümine bağlanmamış kobalt ile renkli bir kompleks oluşturması sağlanır. Oluşan renkli kompleks $500 \mathrm{~nm}$ dalga boyunda spektrofotometrik olarak ölçülür.

Bulgular: AV'li hasta grubunun yaş ortalaması $18,54( \pm 3,40)$, kontrol grubunun yaş ortalaması ise $17,68( \pm 3,37)$ olarak saptandı. AV

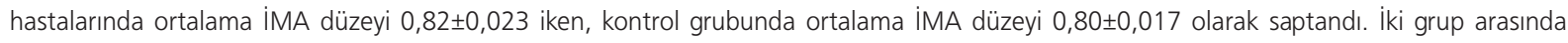
iMA düzeyi açııından istatistiksel olarak anlamlı fark saptandı $(p<0,001)$. AV hastalarının alt grupları arasında iMA düzeyleri açısından anlamlı farkllik tespit edilmedi.

Sonuç: PubMed veri tabanı araştırılığında AV hastalarında iMA düzeylerini araştıran başka çalışmaya rastlanmamıştır.
\end{abstract}

Anahtar Kelimeler: Akne vulgaris, oksidatif stres, iskemi-modifiye albümin

Address for Correspondence/Yazışma Adresi: Gülhan Gürel MD, Yozgat Bozok University Faculty of Medicine, Deparment of Dermatology, Yozgat, Turkey Phone: +90 5069260596 E-mail: gulhanozturkgurel@hotmail.com Received/Geliş Tarihi: 13.06.2018 Accepted/Kabul Tarihi: 11.01.2019 ORCID: orcid.org/0000-0001-5716-8750

(C)Telif Hakkı 2019 Deri ve Zührevi Hastalıklar Derneği

Türkderm-Deri Hastalıkları ve Frengi Arșivi Dergisi, Galenos Yayınevi tarafindan basılmıștır. 


\section{Introduction}

Acne vulgaris (AV) is one of the most common dermatological diseases seen in late childhood and adolescence ${ }^{1}$. AV is a cutaneous inflammatory disease which affects more than $85 \%$ of adolescents worldwide ${ }^{2,3}$. The pathogenesis is multifactorial and is still not fully understood. Follicular hyperkeratinization, sebaceous hyperplasia, and Propionibacterium acnes colonization are the main underlying factors in acne. Inflammation and immune reactions are also instrumental in the pathogenesis ${ }^{4}$. P. acnes leads to the production of many enzymes, such as follicular lipase, protease, and hyaluronidase that are instrumental in the inflammatory period ${ }^{5}$. Reactive oxygen species can also be released from the walls of damaged follicular epithelium, which may contribute to the development of inflammation in the pathogenesis of the disease ${ }^{6}$. Oxidative stress is reported to be effective in the pathogenesis at the onset of acne?

Ischemia-modified albumin (IMA) is a marker whose levels increase secondary to myocardial and skeletal muscle ischemia ${ }^{8}$. Levels of IMA also increase in diseases involving increased oxidative stress, such as obesity, type 2 diabetes mellitus, hypercholesterolemia, preeclampsia and polycystic ovary syndrome $\mathrm{e}^{-11}$.

The purpose of this study is to evaluate IMA levels in $\mathrm{AV}$, a cutaneous inflammatory disease.

\section{Materials and Methods}

Seventy-four patients between 15 and 30 years of age with clinically diagnosed $A V$, and 60 healthy age and sex matched controls without $A V$ were enrolled in the study. The study was explained to the participants, and signed informed consent forms were obtained. Severity of $A V$ was assessed using the global acne grading system. Patients were divided into three categories, mild, moderate and severe AV based on this grading system (Table 1). Subjects with chronic inflammatory disease, alcohol users and smokers, pregnant and breast-feeding women were excluded from the study.

Serum IMA levels were measured using the albumin cobalt binding test. The capacity of cobalt to albumin decreases under ischemic conditions. Patient serum is mixed with cobalt chloride and incubated for 5 minutes, during which the cobalt is allowed to bind to the albumin. This is mixed with dithiothreitol (DTT) following incubation, and result in a colored complex with cobalt unbound to albumin for

\section{Table 1. Global acne grading system}

\begin{tabular}{|l|l|}
\hline Location & Factor \\
\hline Forehead & 2 \\
\hline Right cheek & 2 \\
\hline Left cheek & 2 \\
\hline Nose & 1 \\
\hline Chin & 1 \\
\hline Chest and upper back & 3 \\
\hline $\begin{array}{l}\text { Each type of lesion is given a value depending on severity: no lesions=0, comedones } \\
=1, \text { papules =2, pustules =3 and nodules =4. The score for each area (local score) } \\
\text { is calculated using the formula: local score = factor x grade (0-4). The global score } \\
\text { is the sum of local scores, and acne severity was graded using the global score. A } \\
\text { score of 1-18 is considered mild; 19-30, moderate; } 31 \text {-38, severe; and >39, very } \\
\text { severe }\end{array}$ \\
\hline
\end{tabular}

DTT. The resulting colored complex is measured spectrophotometrically at a wavelength of $500 \mathrm{~nm}$. The study was approved by the Local Ethics Committee of Bozok University (approval number: 2017-KAEK189_2017.12.21_03). Consent form was filled out by all participants.

\section{Statistical Analysis}

The results were subjected to statistical analysis on, "Statistical Package for Social Science for Windows (SPSS v18)". The Kolmogorov-Smirnov test was used to establish continuous variables whether corresponded to normal distribution. Descriptive statistics from continuous variables were expressed as mean \pm standard deviation. Student's t-test was used to compare patients with $\mathrm{AV}$ and the control group. Parametric ANOVA was used for analysis of IMA levels among the subgroups of patients with AV.

\section{Results}

A total of 134 subjects, 74 with $\mathrm{AV}$ and 60 controls, were included in the study. Among 74 patients with $\mathrm{AV}, 38$ of them are female and 36 of them are male, while among 60 controls, 29 of them are female and 31 of them are male. The mean age of the AV group with AV was $18.54( \pm 3.40)$, and the mean age of the control group was 17.68 ( \pm 3.37$)$. There was no statistically significant difference in terms of age or sex between the AV and control groups ( $p>0.05$ ) (Table 2).

The mean IMA level in the AV patients was $0.82 \pm 0.023$, compared to $0.80 \pm 0.017$ in the control group. The difference between the two groups was statistically significant $(p<0.001)$ (Table 2$)$.

Patients with AV were divided into three subgroups, mild, moderate and severe, using the global acne grading system ( $n=25, n=24$ and $n=25$, respectively). No significant difference was determined among the AV subgroups in terms of IMA levels ( $p>0.05$ ) (Table 3).

\section{Discussion}

$\mathrm{AV}$ is the most common dermatological disease, affecting $80 \%$ of people between the ages of 11 and $30^{12}$. The pathogenesis is not clearly

Table 2. Comparison of the ischemia-modified albumin values between the acne vulgaris and control groups

\begin{tabular}{|l|l|l|l|}
\hline Parameter & $\begin{array}{l}\text { Acne vulgaris } \\
\mathbf{n = 7 4}\end{array}$ & $\begin{array}{l}\text { Control } \\
\mathbf{n}=\mathbf{6 0}\end{array}$ & $\mathbf{p}$ \\
\hline Age & $18.54 \pm 3.40$ & $17.68 \pm 3.37$ & 0.14 \\
\hline Sex & $36 / 38$ & $31 / 29$ & $0.72^{*}$ \\
\hline (male/female) & $0.82 \pm 0.023$ & $0.80 \pm 0.017$ & $\mathbf{0 . 0 0 0 *}$ \\
\hline IMA (mean + SD) & 0.001 \\
\hline $\begin{array}{l}\text { *Chi-squared test, * }{ }^{*}<0.001 \\
\text { SD: Standard deviation, IMA: Ischemia-modified albumin }\end{array}$ \\
\hline
\end{tabular}

Table 3. Ischemia-modified albumin values according to global acne grading system

\begin{tabular}{|l|l|l|l|l|}
\hline Parameter & $\begin{array}{l}\text { Mild acne, } \\
\mathbf{n = 2 5}\end{array}$ & $\begin{array}{l}\text { Moderate } \\
\text { acne, } \mathbf{n = 2 4}\end{array}$ & $\begin{array}{l}\text { Severe } \\
\text { acne, } \mathbf{n = 2 5}\end{array}$ & $\mathbf{p}$ \\
\hline $\begin{array}{l}\text { IMA } \\
\text { (mean } \pm S D)\end{array}$ & $0.817 \pm 0.017$ & $0.817 \pm 0.023$ & $0.816 \pm 0.028$ & $0.98^{*}$ \\
\hline $\begin{array}{l}\text { * } p>0.05 \\
\text { SD: Standard deviation, IMA: Ischemia-modified albumin }\end{array}$ \\
\hline
\end{tabular}


understood. $P$. acnes result in the release of some chemotactic factors that cause an accumulation of neutrophils and some inflammatory factors, such as lysosome enzymes, as a result of phagocytosis damage to the follicular epithelium. Reactive oxygen species are released from the active neutrophils in the inflammatory tissue. These oxidants attack DNA and/or membrane lipids and cause chemical injury ${ }^{13}$. Reactive oxygen species synthesized from neutrophils are closely associated with the pathogenesis of various inflammatory skin diseases ${ }^{13,14}$. Arican et al..$^{13}$ measured oxidative stress parameters such as catalase, glucose-6-phosphate dehydrogenase (G6PD), superoxide dismutase and malondialdehyde (the end product of lipid peroxidation) in patients with AV. They reported that while levels of catalase and G6PD statistically decreased significantly, levels of superoxide dismutase and malondialdehyde increased statistically, indicating oxidative stress in acne patients. Sahib et al. ${ }^{15}$ reported significantly higher serum malondialdehyde levels and lower glutathione levels than in healthy controls. Consistent with these findings, Basak et al. ${ }^{16}$ reported significantly lower activities of antioxidants such as superoxide dismutase and glutathione peroxidase in patients with asthma compared with healthy controls.

IMA is a novel and sensitive biomarker of ischemia and oxidative stress. The N-terminal part of human serum albumin is a binding site which binds transition metal ions, cobalt, copper, and nickel. IMA is a form of human serum albumin that can not bind transition metals since the N-terminal part is affected. IMA levels have been reported to increase in diseases capable of causing acute or chronic hypoxia and oxidative stress ${ }^{17}$. IMA levels also increase in diseases that oxidative stress is implicated in etiopathogenesis, such as psoriasis, diabetes mellitus, multiple sclerosis, some cancers, polycystic ovary syndrome and b-thalassemia major ${ }^{10,18-22}$.

Our review of the literature revealed a limited number of studies of IMA and dermatological diseases. Capkin et al. ${ }^{17}$ reported that IMA may be used as an important marker in assessing vascular involvement in patients with Behçet's disease. Similarly, Ozyazgan et al. ${ }^{23}$ observed higher levels of IMA in the active phase of Behcet's disease. Işik et al. ${ }^{18}$ investigated the correlation between the psoriasis area severity index (PASI) and IMA levels in patients with psoriasis and reported significantly higher IMA levels in the psoriasis group than in the control group. IMA levels do not correlate with PASI scores, but have been found to correlate with duration of illness. In our study, the mean IMA level in patients with $A V$ was significantly higher than in the control group. This indicates that IMA, an oxidative stress parameter, may play a role in the pathogenesis of $\mathrm{AV}$. In agreement with previous studies, we determined no significant differences in IMA levels among the AV subgroups. This suggest that the effect on IMA levels in patients with AV may be independent of the severity of the disease, as well as indicating the possible involvement of compensatory mechanisms in the body. Ozdemir et al. ${ }^{24}$ reported that IMA levels increase in patients with psoriasis as an adaptive response to oxidative stress and systemic inflammation.

Ataş et al. ${ }^{25}$ also examined catalase, glutathione-S-transferase, superoxide dismutase and malondialdehyde levels together with IMA in order to investigate the role of oxidative stress in patients with vitiligo. They identified IMA as a statistically significant independent predictor of oxidative stress compared to the control group. They also identified increases in the affected body surface area and age as independent risk factors for IMA.

\section{Study Limitation}

The limitation of our study was small patient population.

\section{Conclusion}

The etiology of $\mathrm{AV}$ is multifactorial, and is still unclear. Oxidative stress is implicated in the initial phase of acne, while IMA is a marker of oxidative stress. We consider that IMA is a triggering factor, in addition to other oxidative stress parameters, in patients with AV. Our search of the Pubmed database revealed no previous studies investigating IMA levels in patients with AV. Ours is therefore the first study of this kind. Further prospective studies involving different patient populations are now needed to support these results.

\section{Ethics}

Ethics Committee Approval: The study was approved by the Local Ethics Committee of Bozok University (approval number: 2017-KAEK189_2017.12.21_03).

Informed Consent: Consent form was filled out by all participants. Peer-review: Externally peer-reviewed.

\section{Authorship Contributions}

Surgical and Medical Practices: G.G., M.K., Concept: G.G., Design: G.G., S.N., M.K., Data Collection or Processing: G.G., M.K., C.B., Analysis or Interpretation: M.K., C.B., S.N., Literature Search: G.G., C.B. Writing: G.G., E.Ç.

Conflict of Interest: No conflict of interest was declared by the authors.

Financial Disclosure: The authors declared that this study received no financial support.

\section{References}

1. Bergfeld WF: The pathophysiology of acne vulgaris in children and adolescents, Part 1. Cutis 2004;74:92-7.

2. Williams HC, Dellavalle RP, Garner S. Acne vulgaris: Lancet 2012;379:361-72.

3. James WD. Clinical practice. Acne. N Engl J Med 2005;352:1463-72.

4. Zouboulis CC, Eady A, Philpott M, Goldsmith LA, Orfanos C, Cunliffe WC, et al: What is the pathogenesis of acne? Exp Dermatol 2005;14:143-52.

5. Burkhart $\mathrm{CN}$ : Clinical assessment of acne pathogenesis with treatment implications. Int Pediatr 2003; 18:14-9.

6. Briganti S, Picardo M: Antioxidant activity, lipid peroxidation and skin diseases. What's new? J Eur Acad Dermatol Venereol 2003;17:663-9.

7. Bataille $V$, Sneider $H$, MacGregor AJ, Sasieni P, Spector TD: The influence of genetics and environmental factors in the pathogenesis of acne: a twin study of acne in women. J Invest Dermatol 2002;119:1317-22.

8. Bar-Or D, Lau E, Winkler JV: A novel assay for cobalt-abumin binding and its potential as a marker for myocardial ischemia a preliminary report. J Emerg Med 2000;19:311-5.

9. Piva SJ, Duarte MM, Da Cruz IB, Coelho AC, Moreira AP, Tonello R, et al: Ischemia-modified albumin as an oxidative stress biomarker in obesity. Clin Biochem 2011:44:345-7.

10. Caglar GS, Oztas E, Karadag D, Pabuccu R, Demirtas S: Ischemia-modified albumin and cardiovascular risk markers in polycystic ovary syndrome with or without insulin resistance. Fertil Steril 2011;95:310-3.

11. Duarte MM, Rocha JB, Moresco RN, Duarte T, Da Cruz IB, Loro VL, et al: Association between ischemia-modified albumin, lipids and inflammation 
biomarkers in patients with hypercholesterolemia. Clin Biochem 2009;42:666-71.

12. Federman DG, Kirsner RS: Acne vulgaris: pathogenesis and therapeutic approach. Am J Manag Care 2000;6:78-87.

13. Arican O, Kurutas EB, Sasmaz S: Oxidative stress in patients with acne vulgaris. Mediators Inflamm 2005;2005:380-4.

14. Al-Shobaili HA: Oxidants and anti-oxidants status in acne vulgaris patients with varying severity. Ann Clin Lab Sci 2014;44:202-7.

15. Sahib AS, Al-Anbari HH, Raghif ARA: Oxidative stress in acne vulgaris: an important therapeutic target. J Mol Pathophysiol 2013;2:27-31.

16. Basak PY, Gultekin F, Kilinc I: The role of the antioxidative defense system in papulopustular acne. J Dermatol 2001;28:123-7.

17. Capkin E, Karkucak M, Kola M, Karaca A, Aydin Capkin A, Caner Karahan S: Ischemia-modified albumin (IMA): a novel marker of vascular involvement in Behçet's disease? Joint Bone Spine 2015;82:68-9.

18. Işik S, Kılıç S, Öğretmen Z, Çakir DÜ, Türkön H, Cevizci S, et al: The correlation between the psoriasis area severity index and ischemia-modified albumin, mean platelet volume levels in patients with psoriasis. Postepy Dermatol Alergol 2016;33:290-3.

19. Ahmad A, Manjrekar P, Yadav C, Agarwal A, Srikantiah RM, Hegde A: Evaluation of ischemia-modified albumin, malondialdehyde, and advanced oxidative protein products as markers of vascular injury in diabetic nephropathy. Biomark Insights 2016;11:63-8.

20. Aydin O, Ellidag HY, Eren E, Kurtulus F, Yaman A, Yilmaz N: Ischemia modified albumin is an indicator of oxidative stress in multiple sclerosis. Biochem Med 2014;24:383-9.

21. Ellidag HY, Eren E, Aydin O, Akgol E, Yalcinkaya S, Sezer C, et al: Ischemia modified albumin levels and oxidative stress in patients with bladder cancer. Asian Pac J Cancer Prev 2013;14:2759-63.

22. Awadallah SM, Atoum MF, Nimer NA, Saleh SA: Ischemia modified albumin: an oxidative stress marker in -thalassemia major. Clin Chim Acta 2012;413:907-10.

23. Ozyazgan S, Andican G, Erman H, Tuzcu A, Uzun H, Onal B, et al: Relation of protein oxidation parameters and disease activity in patients with Behçet's disease. Clin Lab 2013;59:819-25.

24. Ozdemir M, Kiyici A, Balevi A, Mevlitoğlu I, Peru C: Assessment of ischaemiamodified albumin level in patients with psoriasis. Clin Exp Dermatol 2012;37:610-4

25. Ataş H, Kocabıyık M, Gönül M, Öztürk Y, Kavutçu M: Usefulness of ischemiamodified albumin in predicting oxidative stress in patients with vitiligo. Biomark Med 2017;11:439-49. 